\title{
PENGARUH CORPORATE SOCIAL RESPONSIBILITY TERHADAP LABA BANK SYARIAH
}

\author{
Citra Mulya Sari1) \\ 1)IAIN Tulungagung \\ 1)citramulya@yahoo.com
}

\begin{abstract}
Abstrak: Penelitian ini dilatarbelakangi oleh suatu fenomena bahwa pengetahuan dan pemahaman tentang bentuk-bentuk pertanggungjawaban yang dilakukan oleh suatu perusahaan terhadap lingkungannya, bila memberikan kontribusi yang besar maka akan semakin baik citra perusahaan serta meningkatkan kepercayaan masyarakat untuk mempercayakan sebagian dananya. dipercayakan kepada Bank Syariah. Selanjutnya dengan semakin banyaknya perolehan dana pihak ketiga diharapkan dapat mempengaruhi profit bank syariah, begitu pula sebaliknya. Dalam hal ini peneliti menganalisis pengaruh alokasi pengungkapan Dana Qardh Corporate Social Responsibility dan Dana Zakat, Infaq dan Shadaqah terhadap Laba Bank Syariah. Permasalahan dalam penelitian ini adakah hubungan yang signifikan antara Dana Qardh Corporate Social Responsibility dan Dana Zakat, Infaq dan Shadaqah secara simultan terhadap Laba Bank Syariah. Tujuan penelitian ini adalah untuk mengetahui pengaruh Dana Qardh Corporate Social Responsibility dan Dana Zakat, Infaq dan Shadaqah terhadap Laba Bank Syariah dan seberapa signifikan pengaruhnya. Penelitian ini menggunakan metode atau pendekatan kuantitatif dengan desain studi cross sectional. Penelitian ini menggunakan jenis penelitian asosiatif. Data yang digunakan adalah time series. Sumber data yang digunakan adalah data sekunder Laporan Keuangan semesteran PT. Bank BNI Syariah, PT. Bank Syariah Mandiri dan PT. Bank Mega Syariah terdiri atas sumber dan penggunaan qardh, sumber dan penggunaan dana ZIS serta laba dan / atau rugi dengan periode pengamatan 2010-2014. Hasil penelitian menunjukkan bahwa secara parsial dana qardh tidak berpengaruh signifikan terhadap laba bank syariah, sedangkan variabel zakat, infaq dan shadaqah berpengaruh signifikan terhadap laba bank syariah. Secara simultan menunjukkan bahwa kedua variabel yang dianalisis memiliki pengaruh terhadap Laba Bank Syariah dan membuktikan bahwa variabel Dana Qardh dan Dana Zakat, Infaq dan Shadaqah berpengaruh signifikan terhadap Laba Bank Syariah.
\end{abstract}

\section{Kata Kunci: CSR dan Laba.}

Abstract: This research is motivated by a phenomenon that knowledge and understanding of forms of accountability are carried out by a company to its environment, when a major contribution, the better the image of the company and also increasing public confidence to entrust part of the funds entrusted to the Bank Syariah. Furthermore, with the increasing number of third party funds acquisition is expected to affect the profit Islamic Bank, and vice versa. In this case the researchers analyzed the effect of the allocation of the disclosure of Corporate Social Responsibility Qardh Fund and Zakat Fund, Infaq and Shadaqah against Profit 
Islamic Bank. The problem of this research is there a significant relationship between Corporate Social Responsibility Qardh Funds and Zakat Fund, Infaq and Shadaqah simultaneously against Profit Islamic Bank. The purpose of this study was to determine the influence of Corporate Social Responsibility Qardh Fund and Zakat Fund, Infaq and Shadaqah against Profit Islamic Bank and how significant influence. This study uses a quantitative method or approach with cross sectional study design. This study uses a type of associative research. The data used is the time series. Source of data used are secondary data semesters Financial Statements PT. Bank BNI Syariah, PT. Bank Syariah Mandiri and PT. Bank Mega Syariah consisting of sources and uses of qardh, sources and uses of funds ZIS and profit and/or loss with the observation period 2010-2014. The results showed that in partial funds qardh no significant effect on earnings Islamic Bank, while variable zakat, infaq and shadaqah significant effect on Profit Islamic Bank. Simultaneously showed that both variables are analyzed had an influence on earnings Islamic Bank and prove that variable Qardh Fund and Zakat Fund, Infaq and Shadaqah have a significant impact on Profit Islamic Bank.

Keywords: CSR and Profit.

\section{PENDAHULUAN}

Dewasa ini pengambilan keputusan ekonomi dengan hanya melihat kinerja keuangan suatu perusahaan apalagi perusahaan perbankan sudah tidak relevan lagi. Corporate Social Responsibility merupakan suatu bentuk pertanggungjawaban yang dilakukan oleh suatu perusahaan dalam memperbaiki kesenjangan sosial. Semakin banyak bentuk pertanggung-jawaban yang dilakukan oleh suatu perusahaan terhadap lingkungannya, maka semakin baik pula citra perusahaan menurut pandangan masyarakat.

Investor lebih berminat pada perusahaan yang memiliki citra yang baik di masyarakat karena semakin baiknya citra perusahaan, maka semakin tinggi juga loyalitas konsumen. Seiring meningkatnya loyalitas konsumen dalam waktu lama maka penjualan perusahaan akan membaik dan pada akhirnya diharapkan tingkat laba perusahaan juga meningkat. Secara teoritis, suatu perusahaan dikatakan mempunyai nilai yang baik jika laba yang diperoleh perusahaan juga baik.

Corporate Social Responsibility merupakan salah satu kewajiban yang harus dilaksanakan oleh suatu perusahaan yang sesuai dengan isi Undang-Undang Perseroan 
Terbatas No. 40 Tahun 2007 Pasal 74 (1) berbunyi Perseroan yang menjalankan kegiatan usahanya di bidang dan/atau berkaitan dengan sumber daya alam wajib melaksanakan Tanggung Jawab Sosial dan Lingkungan, (2) Tanggung Jawab Sosial dan Lingkungan sebagaimana dimaksud pada ayat (1) merupakan kewajiban Perseroan yang dianggarkan dan diperhitungkan sebagai biaya Perseroan yang pelaksanaannya dilakukan dengan memperhatikan kepatutan dan kewajaran. Pasal 66 ayat (2c) menyatakan bahwa semua perusahaan wajib untuk melaporkan pelaksanaan tanggung jawab sosial dan lingkungan dalam laporan tahunan.

Selain itu, kewajiban pelaksanaan Corporate Social Responsibility juga diatur dalam Undang-Undang Penanaman Modal No. 25 Tahun 2007 Pasal 15 bagian b, Pasal 17 dan Pasal 34 yang mengatur setiap penanam modal diwajibkan untuk ikut serta dalam tanggung jawab sosial perusahaan.

Pemerintah mewajibkan perusahaan-perusahaan untuk melaksanakan Corporate Social Responsibility, yakni dengan menyalurkan 25\% dari net profit untuk kepentingan Corporate Social Responsibility tetapi kewajiban ini bukan merupakan suatu beban yang memberatkan. Perlu diingat bahwa pembangunan suatu negara bukan hanya tanggung jawab pemerintah dan perusahaan saja, tetapi setiap insan manusia berperan untuk mewujudkan kesejahteraan sosial dan pengelolaan kualitas hidup masyarakat.

Alokasi dana Corporate Social Responsibility 5\% yaitu berdasarkan dari konsep zakat yang diwajibkan menyalurkan dana 2,5 \% dari laba bersih untuk yang berhak menerima sesuai dengan landasan syariah, sedangkan sisanya 2,5\% adalah bentuk kedermawanan sekaligus bentuk tanggung jawab Bank Syariah terhadap permasalahanpermasalahan yang tidak terdapat dalam kategori penerima zakat misalnya lingkungan.

Salah satu jenis bank yang memainkan peranan penting dalam pengungkapan dan penerapan tanggung jawab sosial adalah Bank Syariah. Posisi Bank Syariah sebagai lembaga keuangan yang sudah eksis di tingkat nasional maupun internasional harus menjadi lembaga keuangan yang dapat dijadikan contoh dalam menggerakkan program Corporate Social Responsibility. ${ }^{1}$

\footnotetext{
${ }^{1}$ Yusuf Wibisono, Membedah Konsep \& Aplikasi CSR ..., hal. 99
} 
Berdasarkan UU No. 21 Tahun 2008 tentang Perbankan Syariah, Bank Syariah dan UUS dapat menjalankan fungsi sosial, yaitu menerima dana yang berasal dari ZIS (Zakat, Infaq dan Shadaqah) atau dana sosial lainnya dan menyalurkannya kepada organisasi pengelola zakat. Selain itu juga dapat menghimpun dana yang berasal dari wakaf uang dan menyalurkannya kepada pengelola wakaf (nadzir) sesuai kehendak pemberi wakaf (wakif). Pelaksanaan fungsi sosial ini, juga dapat merefleksikan peranan Perbankan Syariah dalam pemerataan kesejahteraan ekonomi umat.

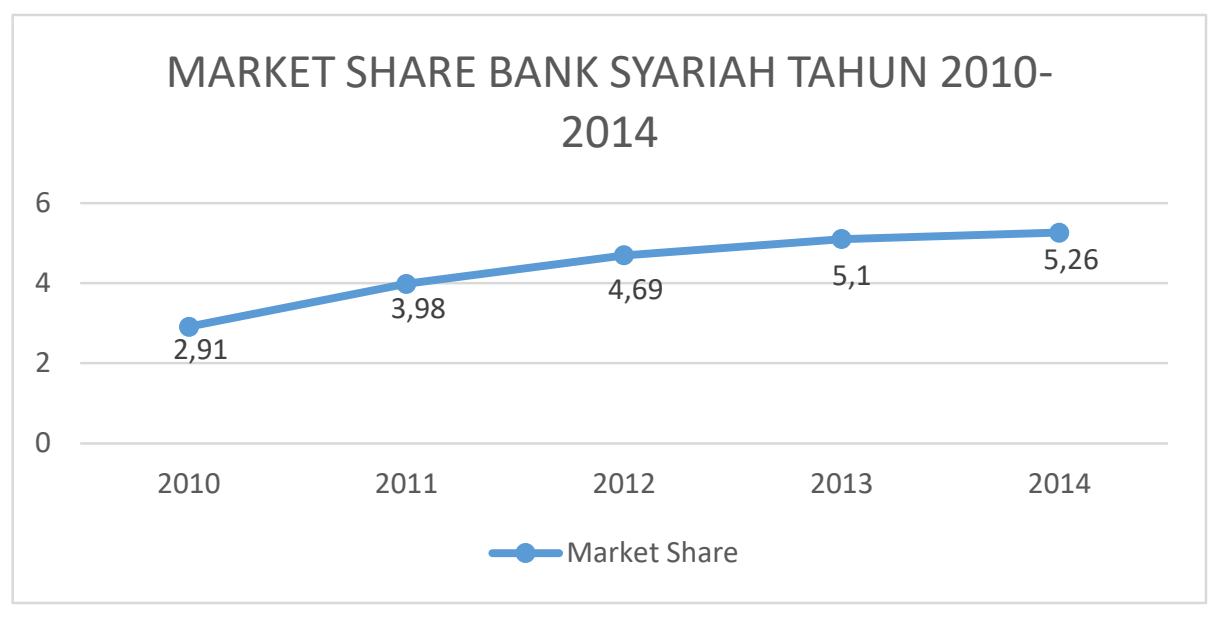

Grafik 1.1

Market Share Bank Syariah Tahun 2010-2014 (dalam persen)

Grafik 1.1 menunjukkan bahwa market share Bank Syariah dari tahun 2010-2014 mengalami peningkatan sebesar 2\% sampai dengan 6\%. Hal ini berarti market share Bank Syariah mengalami perkembangan dan pertumbuhan yang belum signifikan. Sehingga perlu meningkatkan kesadaran dan komitmen dalam pengembangan dana untuk kesejahteraan umat.

Makna Corporate Social Responsibility di dalam penelitian ini didistribusikan ke dalam Dana Qardh dan Dana ZIS (Zakat, Infaq dan Shadaqah). Dana Qardh perbankan diperuntukkan guna dana sosial (tabarru') dan dapat mewujudkan pengembangan usaha mikro, kecil, dan menengah (UMKM). Dalam hal ini Bank Syariah menyalurkan pembiayaan qardh kepada masyarakat yang kondisi ekonominya menengah ke bawah, dimana dana tersebut digunakan untuk usaha atau kegiatan produktif. 
Selain Dana Qardh, ZIS (Zakat, Infaq dan Shadaqah) juga memiliki posisi yang sangat penting, strategis dan menentukan, baik dari sisi doktrin Islam maupun dari sisi pembangunan ekonomi umat termasuk dalam hal pemberantasan kemiskinan.

Bank Syariah diwajibkan menjadi pengelola zakat yang dalam arti wajib membayar zakat, menghimpun, mengadministrasikannya dan menyalurkannya. Pengelolaan dan pendistribusian zakat yang ada di Bank Syariah pada umumnya diserahkan kepada Unit Pelayanan Zakat, baik melalui Badan Amil Zakat setempat, maupun melalui Unit Pelayanan Zakat yang dibentuk oleh Bank bersangkutan. Penyaluran zakat dilakukan bersamaan dengan program Corporate Social Responsibility.

Maka berdasarkan uraian di atas, penulis mengambil judul "Pengaruh Corporate Social Responsibility Dana Qardh dan Dana Zakat Infaq Shadaqah Terhadap Laba Bank Syariah" dengan alasan untuk mengetahui dampak praktek tanggung jawab sosial perusahaan, alokasi Dana Qardh dan Dana ZIS (Zakat, Infaq dan Shadaqah) terhadap Laba Bank Syariah.

\section{KAJIAN TEORI}

\section{Konsep dan Definisi Corporate Social Responsibility}

Teori legitimasi dan teori stakeholder merupakan perspektif teori yang berada dalam kerangka teori ekonomi politik. Karena pengaruh masyarakat luas dapat menentukan alokasi sumber keuangan dan sumber ekonomi lainnya, perusahaan cenderung menggunakan kinerja berbasis lingkungan dan pengungkapan informasi lingkungan untuk membenarkan atau melegitimasi aktivitas perusahaan dimata masyarakat.

Corporate Social Responsibility adalah komitmen perusahaan atau dunia bisnis untuk berkontribusi dalam perkembangan ekonomi yang berkelanjutan dengan memperhatikan tanggung jawab sosial perusahaan yang menitikberatkan pada keseimbangan antara perhatian terhadap aspek ekonomis, sosial dan lingkungan. ${ }^{2}$

${ }^{2}$ Suhandari M. Putri, Schema CSR, Kompas edisi 4 Agustus 2007. 
Tanggung jawab sosial secara lebih sederhana dapat dikatakan sebagai timbal balik perusahaan kepada masyarakat dan lingkungan sekitarnya karena perusahaan telah mengambil keuntungan atas masyarakat dan lingkungan sekitarnya. Proses pengambilan keuntungan tersebut perusahaan seringkali menimbulkan kerusakan lingkungan dan dampak sosial lainnya.

Tanggung jawab merupakan suatu prinsip yang dinamis yang berhubungan dengan keseluruhan perilaku manusia dalam hubunganya dengan masyarakat ataupun institusi. Suatu tanggung jawab bahkan mempunyai kekuatan dinamis untuk mempertahankan kualitas keseimbangan dalam masyarakat.

Definisi Corporate Social Responsibility adalah suatu tindakan atau konsep yang dilakukan oleh perusahaan (sesuai kemampuan perusahaan tersebut) sebagai bentuk tanggungjawab mereka terhadap sosial atau lingkungan sekitar dimana perusahaan itu berada. $^{3}$

Corporate Social Responsibility ialah sebuah pendekatan dimana perusahaan mengintegrasikan kepedulian sosial di dalam operasi bisnis mereka dan dalam interaksi mereka dengan para stakeholder berdasarkan prinsip kemitraan dan kesukarelaan. ${ }^{4}$

Tanggung jawab sosial perusahaan adalah tanggung jawab moral perusahaan terhadap masyarakat. Tanggung jawab ini dapat diarahkan mulai dari dirinya sendiri, kepada karyawan, kepada perusahaan lain, kepada lingkungan sosial bahkan kepada Negara. Untuk melihat secara jelas tentang tanggung jawab sosial perusahaan ini harus dibedakan antara tanggung jawab ekonomis dan tanggung jawab sosial.

Tanggung jawab ekonomis biasanya diukur dengan keberhasilan kinerja perusahaan dan laba yang didapat. Tetapi tanggung jawab ini tidak bisa terpisah misalnya dalam perusahaan-perusahaan milik pemerintah, seperti perusahaan umum kereta api, walaupun dari sisi ekonomis selalu rugi, tetapi karena alasan tanggung jawab sosial perusahaan ini tetap dipertahankan. Dari pandangan ini maka dapat ditarik benang

${ }^{3}$ http://www.usaha-kecil.com/pengertian_csr.html tgl 14 Maret 2015

${ }^{4}$ Ristiuty.edublogs.org/files/2008/04/csr.ppt, tgl 14 Maret 2015 
merah sementara bahwa tanggung jawab sosial berada diluar tanggung jawab ekonomi sebuah perusahaan. ${ }^{5}$

Dalam melihat aplikasinya tanggung jawab sosial dapat dilihat dari dua sisi, yaitu dari sisi positif dan sisi negatif. Secara positif perusahaan dapat melakukan kegiatan yang tidak membawa keuntungan ekonomis dan semata-mata dilangsungkan demi kesejahteraan masyarakat atau salah satu kelompok masyarakat. Sedangkan dari segi negatif perusahaan dapat menahan diri untuk tidak melakukan kegiatan-kegiatan tertentu, yang sebenarnya menguntungkan dari sisi bisnis tetapi akan merugikan masyarakat atau sebagian masyarakat.

Corporate Social Responsibility akan lebih berdampak positif bagi masyarakat; ini akan sangat tergantung dari orientasi dan kapasitas lembaga dan organisasi lain, terutama pemerintah. Studi Bank Dunia menunjukkan, peran pemerintah yang terkait dengan Corporate Social Responsibility meliputi pengembangan kebijakan yang menyehatkan pasar, keikutsertaan sumber daya, dukungan politik bagi pelaku Corporate Social Responsibility, menciptakan insentif dan peningkatan kemampuan organisasi. ${ }^{6}$

Berbisnislah sehebat-hebatnya untuk mengumpulkan keuntungan yang sebanyakbanyak mungkin, namun jangan lupakan dukungan lingkungan. Selain sebagai bentuk tanggung jawab, nantinya lingkungan sekitar dapat menjadi sumber penghasil laba tambahan. Dengan meraih laba dan menumpuk kekayaan secara berkelanjutan tersebut, maka perusahaan dapat tetap exis dan berkembang, sehingga mampu mensejahterakan karyawan serta memakmurkan lingkungan yang ikut menikmati pertumbuhan usaha itu. ${ }^{7}$

Selain itu terdapat beberapa definisi yang berpengaruh diantaranya: Versi WBCSD (World Business Council for Sustainable Development): "The continuing commitment by business to behave ethically and contribute to economic development while improving the quality of work life of workforce and their families as well as of the local community and

${ }^{5}$ Muhammad, Etika Bisnis Islam, (Yogyakarta: Akademi Manajemen Perusahaan YKPN. 2002), hal. 153

${ }^{6}$ http://www.usaha-kecil.com/pengertian_csr.html tgl 14 Maret 2015

${ }^{7}$ Jackie Ambadar, CSR dalam Praktik di Indonesia. (Jakarta: PT Elex Media Komputindo. 2008), hal. 2 
social large", yang berarti bahwa definisi Corporate Social Responsibility adalah komitmen bisnis yang berkelanjutan untuk berperilaku etis dan berkontribusi terhadap pembangunan ekonomi dengan meningkatkan kualitas kehidupan kerja karyawan dan kerja mereka dan komunitas lokal dan masyarakat yang luas. ${ }^{8}$

Versi Bank Dunia (World Bank): "Corporate Social Responsibility is the commitment of business to contribute to sustainable economic development working with employees and their representatives, the local community and society at large to improve quality of life, in ways that are both good for business and good for development", yang berarti bahwa definisi Corporate Social Responsibility adalah komitmen bisnis untuk memberikan kontribusi perkembangan ekonomi yang berkelanjutan dengan karyawan dan perwakilannya, kominitas lokal dan masyarakat yang luas untuk meningkatkan kualitas hidup, melalui jalan bisnis dan perkembangan yang baik. ${ }^{9}$

\section{Tujuan Dan Manfaat Corporate Social Responsibility}

Program Corporate Social Responsibility pada dasarnya bertujuan untuk menjadi jaminan pertumbuhan ekonomi berkelanjutan bagi dunia bisnis atau usaha. Diharapkan bentuk tanggung jawab perusahaan ini benar-benar bermanfaat untuk pemangku kepentingan (masyarakat sekitar, buruh atau pekerja, pemerintah atau pajak, pemerintah setempat atau pertumbuhan ekonomi daerah dan pengusaha). Hal ini dimaksudkan supaya Corporate Social Responsibility benar-benar menjadi titik sentral pembangunan yang berkelanjutan.

Social Business Enterpreneurship (SBE) yang menyatakan bahwa tujuan dari Corporate Social Responsibility adalah upaya dari perusahaan berskala besar untuk bertahan dengan menghindari enclave, namun masih tetap memprioritaskan stakeholder (pemilik modal atau saham) dan tidak sampai pada kesetaraan dan keadilan sosial atau mengurangi kesenjangan sosial. Social Business Enterpreneurship berpihak pada kelompok miskin dengan sikap konkrit yaitu bisnis bukan sekedar profit oriented semata,

\footnotetext{
${ }^{8}$ Yusuf Wibisono, Membedah Konsep \& Aplikasi CSR, (Gresik: Fascho Publishing, 2007), hal. 7

${ }^{9}$ Ibid., hal. 8
} 
akan tetapi berfungsi juga sebagai mesin pencetak kesejahteraan, membebaskan masyarakat dari kemiskinan dan keterbelakangan. ${ }^{10}$

Dengan demikian bisa dirumuskan pula manfaat dari Corporate Social Responsibility tersebut yaitu disampaikan oleh Wibisono yang mengungkapkan 10 manfaat Corporate Social Responsibility, yakni :

1. Mempertahankan atau mendongkrak reputasi dan brand image perusahaan.

2. Layak mendapatkan social license to operate.

3. Mereduksi risiko bisnis perusahaan.

4. Melebarkan akses sumber daya.

5. Membentangkan akses menuju market.

6. Mereduksi biaya.

7. Memperbaiki hubungan dengan stakeholders.

8. Memperbaiki hubungan dengan regulator.

9. Meningkatkan semangat dan produktivitas karyawan.

10. Peluang mendapatkan penghargaan ${ }^{11}$

\section{Aplikasi Corporate Social Responsibility}

Penyusunan aplikasi Corporate Social Responsibility dimulai dengan menentukan arah dan lingkup jangka panjang yang berkenaan dengan pengaplikasian program Corporate Social Responsibility nanti. Aplikasi yang baik harus mengidentifikasi arah keseluruhan yang dituju. Kemudian melakukan pendekatan mendasar, menentukan prioritas yang spesifik dan merumuskan langkah-langkah selanjutnya yang akan ditempuh. Aplikasi yang dilakukan harus membantu perusahaan memastikan bahwa perusahaan secara berkesinambungan membangun, memelihara dan memperkuat identitas dan pangsa pasar yang telah dimiliki. ${ }^{12}$

Langkah-langkah aplikasi terencana dalam Corporate Social Responsibility yaitu :

\footnotetext{
${ }^{10}$ Ardianto Elvinaro, Metodologi Penelitian untuk Public Relations: Kuantitatif dan Kualitatif. (Bandung : Simbiosa Rekatama Media, 2011), hal. 40-41

${ }^{11}$ Yusuf Wibisono, Membedah Konsep \& Aplikasi CSR..., hal. 23

${ }^{12}$ Susanto, Reputation-Driven Corporate Social Responsibility, (Jakarta: Erlangga), hal. 51-52.
} 
1. Pertama, membentuk tim kepemimpinan program Corporate Social Responsibility yang mencakup perwakilan dari dewan direksi, top manajemen dan pemilik, serta sukarelawan dari unit dalam perusahaan.

2. Kedua, merumuskan program Corporate Social Responsibility yang akan menjadi landasan bagi aktivitas penilaian selanjutnya. Dapat juga diidentifikasi nilai-nilai kunci yang memotivasi perusahaan, melibatkan orang-orang pada setiap tingkatan perusahaan dan menjamin tercapainya tujuan dan penerimaan pengaplikasian program Corporate Social Responsibility yang dilakukan.

3. Ketiga, melakukan kajian terhadap terhadap dokumen, proses, dan aktivitas perusahaan. Dokumen ini dapat mencakup misi perusahaan, kebijakan, code of conduct, prinsip-prinsip usaha dan dokumen-dokumen operasional lainnya yang berhubungan dengan program Corporate Social Responsibility perusahaan atau dapat juga mencakup dokumen eksternal yang berhubungan dengan program yang melibatkan perusahaan.

4. Keempat, mengidentifikasikan dan melibatkan stakeholder kunci, berdiskusi dengan stakeholder kunci khususnya eksternal. Hal ini sangat penting dilakukan untuk "memetakan" kepentingan mereka miliki dengan kepentingan keberlangsungan perusahaan.

5. Kelima, memutuskan target sasaran publik, program yang akan digunakan sesuai dengan keadaan publiknya dan pengaplikasian dan penerapannya di lapangan.

\section{Corporate Social Responsibility dalam Kerangka Islam}

Tanggung jawab sosial perusahaan merupakan tema yang harus berkembang dalam dunia bisnis. Dalam konteks perusahaan terdapat tiga pandangan mengenai tanggung jawab sosial perusahaan. Pertama, para manajer secara jujur memfokuskan bagi kepentingan perusahaan dengan demikian ia merupakan agen untuk mencapai kesejahteraan, stakeholders perusahaan. Kedua, para manajer mempunyai tugas untuk menyeimbangkan kepentingan pokok dan para pelaku perusahaan. Ketiga, para manajer 
bertangung jawab dalam melayani masyarakat, yakni dengan program-program sosial yang menguntungkan masyarakat. ${ }^{13}$

Corporate Social Responsibility merupakan fenomena strategi perusahaan yang mengakomodasi kebutuhan dan kepentingan stakeholder-nya. Corporate Social Responsibility timbul sejak era dimana kesadaran akan sustainability perusahaan jangka panjang adalah lebih penting daripada sekedar profitability. ${ }^{14}$

Menurut Sayyid Qutb, Islam mempunyai prinsip pertanggungjawaban yang seimbang dalam segala bentuk dan ruang lingkupnya. Antara jiwa dan raga, individu dan keluarga, individu dan sosial dan antara suatu masyarakat dengan masyarakat lain. Tanggung jawab sosial merujuk pada kewajiban-kewajiban sebuah perusahaan untuk melindungi dan memberi kontribusi kepada masyarakat dimana perusahaan itu berada. Sebuah organisasi mengemban tanggung jawab sosial dalam tiga domain:

1. pada pelaku organisasi, meliputi:

a. Hubungan Perusahaan dengan Pekerja

b. Hubungan Pekerja dengan Perusahaan

c. Hubungan Perusahaan dan Pelaku Usaha Lain; distributor, konsumen, pesaing.

2. pada lingkungan alam

3. pada kesejahteraan sosial secara umum. ${ }^{15}$

\section{Dana Qardh}

Secara etimologi, qarada-yaqridu berarti memotong. Dikatakan demikian karena harta tersebut benar-benar dipotong apabila diberikan kepada peminjam. Secara terminologi (istilah) qardh (qardhul hasan) dapat didefinisikan pinjaman tanpa imbalan yang memungkinkan peminjam untuk menggunakan dana tersebut selama jangka waktu tertentu dan wajib mengembalikan dalam jumlah yang sama pada akhir periode yang

\footnotetext{
${ }^{13}$ Muhammad, Etika Bisnis Islam..., hal. 152

${ }^{14}$ http://www.usaha-kecil.com/pengertian_csr.html tgl 14 Maret 2015.

${ }^{15}$ Rafik Issa Beekum, Etika Bisnis Islam. (University of Nevada November I, 1996), hal 63.
} 
telah disepakati. Qardhul hasan merupakan fungsi sosial pada Perbankan Syariah di mana dananya diambil dari dana kebajikan.

Al-Qardh adalah pemberian harta kepada orang lain yang dapat ditagih atau diminta kembali atau dengan kata lain meminjamkan tanpa mengharapkan imbalan. ${ }^{16}$ Dalam literatur fiqih klasik, qardh dikategorikan dalam aqd tathawwui atau akad saling membantu dan bukan transaksi komersial. ${ }^{17}$

Landasan Hukum

Al-Qur'an

Artinya: "Siapakah yang mau meminjamkan kepada Allah pinjaman yang baik, Allah akan melipatgandakan (balasan) pinjaman itu untuknya dan dia akan memperoleh pahala yang banyak."18

Yang menjadi landasan dalil dalam ayat di atas adalah kita diseru untuk "meminjamkan kepada Allah", yang artinya untuk membelanjakan harta dijalan Allah. Selain itu kita diseru untuk meminjamkan kepada sesama manusia sebagai bagian dari civil society.

\section{Al-Hadits}

Anas bin Malik berkata bahwa Rasulullah berkata, "Aku melihat pada waktu malam diisra'kan, pada pintu surga tertulis : sedekah dibalas sepuluh kali lipat dan qardh delapan belas kali. Aku bertanya, 'Wahai Jibril, mengapa qardh lebih utama dari sedekah?' Ia menjawab, 'Karena peminta-minta sesuatu dan ia punya, sedangkan yang meminjam tidak akan meminjam kecuali karena keperluan".19

Aplikasi dalam Perbankan

1. Sebagai produk pelengkap kepada nasabah yang telah terbukti loyalitas dan bonafiditasnya, yang membutuhkan dana talangan segera untuk masa yang relatif

\footnotetext{
${ }^{16}$ Muhammad Syafi'i Antonio, Bank Syariah: Dari Teori ke Praktik. (Jakarta: Gema Insani Press, 2001), hal. 131

${ }^{17}$ Ahmad asy-Syarbasyi, al Mu'jam al Iqtisad al-Islami. (Beirut: Dar Alamil Kutub, 1987); Sayyid Sabiq, Fiqhus Sunnah (Beirut: Darul-Kitab al-Arabi, 1987), cetakan ke-8, vol.III, hal. 163

${ }^{18} \mathrm{Al}$ Qur'an dan Terjemahannya dalam Q.S Al Hadiid ayat 11

${ }^{19}$ Hadits Riwayat Ibnu Majah no. 2422, Kitab al-Ahkam, dan Baihaqi
} 
pendek. Nasabah tersebut akan mengembalikan secepatnya sejumlah uang yang dipinjamnya itu.

2. Sebagai fasilitas nasabah yang memerlukan dana cepat, sedangkan ia tidak bisa menarik dananya karena misalnya, tersimpan dalam bentuk deposito.

3. Sebagai produk untuk menyumbang usaha yang sangat kecil atau membantu sektor sosial. Untuk pemenuhan skema khusus ini telah dikenal suatu produk khusus yaitu al-qardhul hasan. ${ }^{20}$

Sumber Dana

Sifat al-qardh tidak memberi keuntungan financial. Karena itu, pendanaan qardh dapat diambil menurut kategori berikut ini:

1. Al-qardh yang diperlukan untuk membantu keuangan nasabah secara cepat dan berjangka pendek. Talangan dana di atas dapat diambilkan dari modal bank.

2. Al-qardh yang diperlukan untuk membantu usaha yang sangat kecil dan keperluan sosial, dapat bersumber dari dana zakat, infaq dan shadaqah. Sumber dana lain yang dapat dialokasikan untuk al-qardh adalah pendapatan-pendapatan yang diragukan, seperti jasa nostro di bank koresponden yang konvensional dan bunga atas jaminan L/C di bank asing.

Manfaat al-qardh

1. Memungkinkan nasabah yang sedang dalam kesulitan mendesak untuk mendapatkan talangan jangka pendek.

2. Al-qardhul hasan juga merupakan salah satu ciri pembeda antara bank syariah dan bank konvensional yang didalamnya terkandung misi sosial, jadi tidak hanya misi komersial.

3. Adanya misi sosial-kemasyarakatan ini akan meningkatkan citra baik dan meningkatkan loyalitas masyarakat terhadap Bank Syariah.

Risiko dalam al-qardhul hasan terhitung cukup tinggi karena dia dianggap pembiayaan yang tidak ditutup dengan jaminan apapun.

Akad qardh biasanya diterapkan sebagai hal berikut:

${ }^{20}$ Muhammad Syafi'i Antonio, Bank Syariah: Dari Teori ke Praktik..., hal. 133. 
1. Sebagai produk pelengkap kepada nasabah yang telah terbukti loyalitas dan bonafiditasnya, yang membutuhkan dana talangan segera untuk masa yang relatif pendek. Nasabah tersebut akan mengembalikan secepatnya sejumlah uang yang dipinjam itu.

2. Sebagai fasilitas nasabah yang memerlukan dana cepat, sedangkan ia tidak bisa menarik dananya karena, misalnya, tersimpan dalam bentuk deposito.

3. Sebagai produk untuk menyumbang usaha yang sangat kecil atau membantu sektor sosial. Guna pemenuhan skema ini telah dikenal suatu produk khusus yaitu qardhul hasan.

\section{Dana Zakat, Infaq dan Shadaqah}

Dalam ibadah maaliyah (harta) ada tiga istilah yang digunakan. Karena perbedaan istilah, maka ada perbedaan dalam hukum dan tata caranya. Ketiga istilah tersebut antara lain Zakat, Infaq dan Shadaqah. Zakat merupakan istilah untuk ibadah harta yang hukumnya wajib dan ketentuannya sudah termaktub dalam Al-Quran dan Hadits. Infaq merupakan istilahi ibadah harta yang hukumnya wajib tetapi ketentuannya tidak dibuat oleh Allah dan Rasulullah. Dan, shadaqah adalah sebutan untuk ibadah harta yang hukumnya sunnah.

Hanya ada dua hukum dalam ibadah maaliyah ini, yaitu wajib dan sunnah. Menurut para ulama, wajib adalah: "Sesuatu yang diganjar jika mengamalkannya dan disanksi jika meninggalkannya". Sedangkan sunnah adalah: "Sesuatu yang diganjar jika mengamalkannya dan tidak disanksi jika meninggalkannya". Letak perbedaan kedua hukum tersebut adalah adanya reward dan punishment. Mengamalkan yang wajib, mendapat reward dan meninggalkannya mendapat punishment. Mengamalkan yang sunat memperoleh reward tetapi meninggalkannya tidak diberi punishment.

Kata zakat merupakan isim mashdar dari kata zakā yang berarti berkah, tumbuh, bersih dan baik. Sedangkan menurut istilah zakat adalah menyerahkan harta tertentu untuk orang tertentu yang telah ditentukan syara' dengat niat karena Allah. Dalam kitab al-Hawi, al-Mawardi memberikan definisi zakat sebagai berikut: "Zakat merupakan 
sebutan untuk pengambilan sesuatu yang khusus dari harta tertentu, berdasarkan sifatsifat tertentu untuk disalurkan kepada golongan tertentu".

Infaq berasal dari kata nafaqa yang berarti telah lewat, berlalu, habis, mengeluarkan isi, menghabiskan miliknya, atau belanja. Menurut istilah, infaq adalah: "Mengeluarkan harta yang thayyib (baik) dalam ketaatan atau hal-hal yang dibolehkan".

Shadaqah berasal dari kata ash-shidqu yang berarti benar atau jujur. Falsafahnya, shadaqah merupakan bukti bahwa seseorang memiliki keyakinan (aqidah) yang benar, jalan hidup (Syariah) yang benar dan prilaku (akhlak) yang benar. selain itu, shadaqah merupakan manifestasi kejujuran seseorang dalam kepemilikan harta. Shadaqah adalah: "Sesuatu yang diberikan untuk mendekatkan diri kepada Allah Ta'ala".

\section{Laba}

Commite On Terminology dalam Aliyal Azmi mendefinisikan laba sebagai jumlah yang berasal dari pengurangan harga pokok produksi, biaya lain dan kerugian dari penghasilan atau penghasilan operasi. Laba adalah pengambilan atas investasi kepada pemilik. ${ }^{21} \mathrm{Hal}$ ini mengukur nilai yang dapat diberikan oleh entitas kepada investor dan entitas masih memiliki kekayaan yang sama dengan posisi awalnya.

Laba dimaknai sebagai imbalan atas upaya perusahaan menghasilkan barang dan jasa. ${ }^{22}$ Ini berarti laba merupakan kelebihan pendapatan diatas biaya (biaya total yang melekat dalam kegiatan produksi dan penyerahan barang atau jasa). Angka terakhir dalam laporan laba rugi adalah laba bersih (net income). ${ }^{23}$ Jumlah ini merupakan kenaikan bersih terhadap modal. Sebaliknya, apabila perusahaan menderita rugi, angka terakhir dalam laporan laba rugi adalah rugi bersih (net loss).

\footnotetext{
${ }^{21}$ Stice James, et. all., Akuntansi Keuangan, (Jakarta: Salemba Empat, 2009), hal. 240

${ }^{22}$ Suwardjono, Teori Akuntansi: Perekayasaan Pelaporan Keuangan. (Yogyakarta: BPFE, 2008), hal. 464

${ }^{23}$ Soemarso SR, Akuntansi Suatu Pengantar, (Jakarta: Salemba Empat, 2004), hal. 227
} 


\section{METODE PENELITIAN}

\section{Pendekatan dan Jenis Penelitian}

Metode penelitian atau pendekatan yang digunakan adalah kuantitatif dengan desain penelitian cross sectional. Desain penelitian cross sectional adalah desain lintas kasus akan tetapi data dijadikan satu. Penelitian ini menggunakan jenis penelitian asosiatif. Penelitian asosiatif adalah suatu metode penelitian yang berusaha mencari hubungan antara satu variabel dengan variabel lain. Hubungannya bisa simetris, kausal, atau interaktif. Dalam penelitian ini untuk mengetahui pengaruh Corporate Social Responsibility Dana Kebajikan dan Dana Zakat, Infaq dan Shadaqah terhadap Laba Bank Syariah. Teknik analisis penelitian asosiatif menggunakan teknik analisis kuantitatif (statistik).

\section{Populasi, Sampling dan Sampel Penelitian}

Populasi dan sampel dalam penelitian ini adalah PT. Bank BNI Syariah, PT. Bank Syariah Mandiri dan PT. Bank Mega Syariah yang beroperasi secara terus menerus selama periode penelitian tahun 2010-2014 yang mempublikasikan laporan keuangan semester untuk periode tahun 2010-2014. Sampling atau teknik yang digunakan dalam penelitian ini adalah purposive sampling. Purposive sampling merupakan teknik pengambilan sampel berdasarkan pertimbangan tertentu, dan pertimbangan dalam penelitian ini adalah periode waktu yang digunakan.

\section{Sumber Data, Variabel dan Skala Pengukuran}

Sumber data yang digunakan adalah data sekunder yaitu Annual Report dan Laporan Keuangan Konsolidasian PT. Bank BNI Syariah, PT. Bank Syariah Mandiri dan PT. Bank Mega Syariah yang terdiri atas laporan posisi keuangan, laporan sumber dan penggunaan qardh, laporan sumber dan penggunaan dana ZIS serta perhitungan laba/ rugi komprehensif dan saldo laba. Selain itu, memperoleh data dari studi literatur, artikel, dan jurnal. Data yang digunakan adalah time series. Variabel independen dalam penelitian ini adalah Corporate Social Responsibility Dana Qardh ( $\left.\mathrm{X}_{1}\right)$ dan Corporate Social Responsibility Dana ZIS (Zakat, Infaq dan Shadaqah) ( $\left.\mathrm{X}_{2}\right)$. Variabel dependen dalam penelitian ini adalah Laba Bank Syariah (Y). 


\section{Teknik Pengumpulan Data dan Instrumen Penelitian}

Teknik pengumpulan data dalam penelitian ini adalah observasi. Selain itu, teknik pengumpulan data juga menggunakan studi pustaka yaitu dengan cara mengumpulkan data dengan membaca buku atau bahan-bahan yang berhubungan dengan masalah yang dibahas dalam penelitian. Instrumen penelitian yang digunakan adalah laporan keuangan PT. Bank BNI Syariah, PT. Bank Syariah Mandiri dan PT. Bank Mega Syariah dengan tahun pengamatan periode tahun 2010-2014 menggunakan data sekunder yaitu laporan keuangan Perbankan Syariah.

\section{Teknik Analisis Data}

\section{a. Analisis Data Penelitian}

Teknik yang dipakai dalam penelitian ini adalah teknik kuantitatif. metode penelitian kuantitatif adalah penelitian ilmiah yang sistematis terhadap bagian-bagian dan fenomena serta hubungan-hubungannya.

Agar kesimpulan yang diambil dapat tepat dan data dapat dianalisis dengan baik, maka diperlukan data yang valid dan reliabel. Sesuai dengan permasalahan penelitian sebagaimana dikemukakan sebelumnya, maka data yang dikumpulkan adalah laporan keuangan publikasi semester yang dimiliki Bank Syariah.

Adapun teknik analisis data yang dipergunakan dalam penelitian ini dijabarkan sebagai berikut :

\section{b. Analisis Deskriptif}

Sebelum dilakukan regresi data yang telah dikumpulkan akan dianalisis dengan melakukan statistik deskriptif. Statistik deskriptif memberikan gambaran atau deskripsi suatu data yang dilihat dari nilai rata-rata (mean), standar deviasi, varian, maksimum, dan minimum.

Statistik deskriptif memiliki kegunaan pokok untuk melakukan pengecekan terhadap input data, karena analisis ini menghasilkan resume data secara umum. Statistik Deskripstif digunakan untuk melihat informasi pengungkapan Corporate Social Responsibility Dana Kebajikan dan Dana Zakat, Infaq dan Shadaqah serta pengaruhnya 
terhadap laba pada Bank Syariah (PT. Bank BNI Syariah, PT. Bank Syariah Mandiri dan PT. Bank Mega Syariah).

\section{c. Analisis Regresi Linier Berganda}

Regresi linier berganda adalah untuk mengestimasi besarnya koefisien-koefisien yang dihasilkan oleh persamaan yang bersifat linier, yang mengakibatkan dua variabel bebas, untuk digunakan sebagai alat prediksi besar nilai variabel tergantung. ${ }^{24}$

Kegunaan analisis ini adalah untuk menghitung besarnya pengaruh dua variabel bebas terhadap satu variabel tergantung dan memprediksi variabel tergantung dengan menggunakan tiga variabel bebas.

Analisis regresi linier berganda digunakan oleh peneliti, peneliti bermaksud meramalkan bagaimana keadaan (naik turunnya) variabal dependen (kriterium), bila dua atau lebih variabel independen sebagai faktor predictor dimanipulasi (dinaik turunkan nilainya). ${ }^{25}$

Persamaan regresi berganda dalam penelitian ini adalah sebagai berikut:

$\mathrm{Y}=\mathrm{a}+\mathrm{b}_{1} \mathrm{X}_{1}+\mathrm{b} 2 \mathrm{X}_{2}+\mathrm{e}$

Keterangan:

Y = Laba Bank Syariah

$\mathrm{a}=$ Konstanta

$\mathrm{b}_{1}=$ Koefisien regresi untuk $\mathrm{X}_{1}$

$\mathrm{b}_{2}=$ Koefisien regresi untuk $\mathrm{X}_{2}$

$\mathrm{X}_{1}=$ Corporate Social Responsibility Dana Qardh

$\mathrm{X}_{2}=$ Dana ZIS (Zakat, Infaq dan Shadaqah)

$\mathrm{e}=$ Standar eror

\section{Uji Linieritas}

Sebelum analisis regresi dilaksanakan, terlebih dahulu dilakukan pengujian linieritas yaitu uji normalitas data dan bebas dari uji asumsi klasik. Uji asumsi klasik

\footnotetext{
${ }^{24}$ Jonathan Sarwono, Metode Penelitian Kuantitatif \& Kualitatif, (Yogyakarta: Graha Ilmu, 2006), hal. 128.

${ }^{25}$ Sugiyono, Statistik Untuk Penelitian, (Bandung: Alfabeta, 2011), hal. 275
} 
berguna untuk menguji bahwa model regresi linier merupakan model yang baik. Model regresi yang digunakan dalam menguji hipotesis haruslah menghindari kemungkinan terjadinya penyimpangan asumsi klasik. Model regresi dikatakan baik apabila terdistribusi secara normal, tidak mengandung multikolinieritas, autokorelasi dan heteroskedastisitas. Untuk itu perlu dilakukan pengujian asumsi klasik yang terdiri dari:

\section{Uji Normalitas}

Uji Normalitas bertujuan untuk menguji apakah model regresi variabel pengganggu atau residual memiliki distribusi normal, seperti diketahui bahwa uji t dan F mengasumsikan bahwa nilai residual mengikuti distribusi normal, kalau asumsi ini dilanggar, maka uji statistik menjadi tidak valid untuk jumlah sampel kecil. Uji statistik yang digunakan yaitu uji statistik non parametrik KS (Kolomogorov Smirnov). Uji ini dilakukan dengan berpedoman:

(a) Nilai Sig. atau signifikansi atau nilai probabilitas $<0,05$, distribusi data adalah tidak normal.

(b) Nilai Sig. atau signifikansi atau nilai probabilitas $>0,05$, distribusi data adalah normal.

\section{Uji Heterokedastisitas}

Uji Heterokedastisitas bertujuan menguji apakah dalam model regresi terjadi ketidaksamaan varian dari residual satu pengamatan ke pengamatan yang lain. Jika varian dari residual satu pengamatan ke pengamatan lain tetap, maka disebut homokedastisitas, dan jika berbeda disebut heterokedastisitas. Model Regresi yang baik adalah Homokedastisitas dan tidak terjadi Heterokedastisitas.

\section{Uji Multikolonieritas}

Uji multikolonieritas bertujuan untuk menguji apakah model regresi ditemukan adanya korelasi antar variabel bebas (independen). Untuk mendeteksi ada dan tidaknya multikolinier di dalam model regresi adalah sebagai berikut:

(a) Nilai $\mathrm{r}^{2}$ yang dihasilkan oleh suatu estimasi model regresi empiris sangat tinggi, tetapi secara individual variabel-variabel independen banyak yang tidak signifikan mempengaruhi variabel dependen. 
(b) Menganalisis matrik korelasi variabel-variabel independen. Jika antara variabel independen ada korelasi cukup tinggi (umumnya diatas 0,80) maka hal ini merupakan indikasi adanya multikolinearitas.

(c) Pengujian korelasi parsial

(d) Regresi subsider atau tambahan. Mengingat multikolinieritas muncul karena salah satu atau lebih variabel penjelas adalah kombinasi pasti linier, salah satu cara untuk mengetahui variabel bebas mana yang sangat kolinier dengan variabel bebas lainnya adalah dengan meregresikan masing-masing variabel bebas terhadap variabel bebas lainnya untuk mengetahui $\mathrm{R}^{2}$ terkait.

(e) Multikolinieritas dapat juga dilihat dari (1) nilai tolerence dan (2) variance inflation factor (VIF). Kedua ukuran ini menunjukkan setiap variabel independen manakah yang dijelaskan oleh variabel independen lainnya. Tolerance mengukur variabel independen yang terpilih yang tidak dapat dijelaskan oleh variabel independen lainnya, jadi nilai tolerance yang rendah sama dengan nilai VIF ynag tinggi (karena VIF $=1 /$ tolerence). Nilai cut-off yang umum dipakai untuk menunjukkan adanya multikolonieritas adalah nilai tolerence $\leq 0.10$ atau sama denagn nilai VIF $\geq 10$.

\section{Uji Autokorelasi}

Uji autokorelasi bertujuan menguji apakah dalam model regresi linier ada korelasi antara kesalahan pengganggu pada periode $\mathrm{t}$ dengan kesalahan pada periode $\mathrm{t}-1$ (sebelumnya). Jika terjadi korelasi maka dinamakan problem autokorelasi.

Untuk memeriksa adanya otokorelasi, biasanya dipakai Uji Durbin-Watson dengan langkah-langkah:

(a) Tentukan hipotesis: Ho: $\rho=0$

$$
\text { Ha: } \rho \neq 0
$$

(b) Menghitung nilai statistik Durbin-Watson (DW)

(c) Bandingkan nilai DW hitung dengan nilai teoritisnya seperti di bawah ini:

Untuk $\rho>0$ (autokorelasi positif):

(a) Jika DW $>$ du dengan $\mathrm{dk}=\mathrm{n}-\mathrm{k}-1$ maka Ho diterima

(b) Jika DW $<$ dl dengan dk = n-k-1 maka Ho ditolak 
(c) Jika $\mathrm{dL}<\mathrm{DW}<\mathrm{du}$, maka tidak dapat diambil kesimpulan

Untuk $\rho>0$ (autokorelasi negatif):

(a) Jika $(4-D W)=$ du maka Ho diterima

(b) Jika $(4-D W)=$ dl maka Ho ditolak

(c) Jika $\mathrm{dL}<(4-\mathrm{DW})<\mathrm{du}$, maka tidak ada keputusan apakah terdapat autokorelasi atau tidak ada model:

\section{Uji F}

Uji statistk F pada dasarnya menunjukan apakah semua variabel independen dimasukkan dalam model yang mempunyai pengaruh bersama-sama terhadap variabel dependen, untuk menguji hipotesis ini digunakan statistik $\mathrm{F}$ dengan kriteria pengambilan keputusan bahwa apabila nilai F lebih besar daripada 4 maka hipotesis awal ditolak pada tingkat kepercayaan 5\%. Dengan kata lain hipotesis alternative yang menyatakan bahwa semua variabel independen secara serentak dan signifikan mempengaruhi variabel dependen dapat diterima. Tahapan uji F sebagai berikut:

a) Merumuskan hipotesis

$\mathrm{HO}: \mathrm{b}_{1}=\mathrm{b}_{2}=\mathrm{b}_{3}=0$,

tidak ada pengaruh variabel independent terhadap variabel dependent

$\mathrm{H} 1: \mathrm{b}_{1} \neq \mathrm{b}_{2} \neq \mathrm{b}_{3} \neq \mathrm{b}_{4} \neq 0$,

minimal ada satu pengaruh dari variabel independent terhadap variabel dependent.

b) Menentukan tingkat signifikasi $(\alpha)$ dengan degree of freedom (df) dengan rumus $\mathrm{n}-\mathrm{k}$

- 1 dengan tujuan untuk menentukan $\mathrm{F}$ tabel

\section{Uji T}

Pengujian hipotesis kedua yaitu diduga variabel Corporate Social Responsibility dana ZIS (Zakat, Infaq dan Shadaqah) memiliki pengaruh yang dominan terhadap Laba Bank Syariah. Dalam hal ini peneliti menggunakan rumus uji t. Uji t digunakan untuk menguji pengaruh masing-masing variabel bebas $\mathrm{X}_{1}$ (Corporate Social Responsibility Dana Qardh) dan X2 (Corporate Social Responsibility dana ZIS (Zakat, Infaq dan Shadaqah) terhadap variabel terikat (Y) Laba Bank Syariah. 
Pengujian secara parsial dari masing-masing variabel bebas terhadap variabel terikat, uji t yang digunakan untuk mengetahui pengaruh variabel independen terhadap variabel dependen. Uji t ini pada dasarnya untuk menunjukan seberapa jauh pengaruh satu variabel penjelas/independen secara individual dalam menerangkan variasi variabel dependen. Uji t digunakan untuk menemukan pengaruh paling dominan antara masingmasing variabel independen untuk menjelaskan variabel dependen dengan tingkat signifikansi 5\%, yakni dengan membandingkan thitung masing-masing variabel bebas dengan tabel pada taraf nyata $\alpha=0,05$.

\section{Koefisien Determinasi}

Untuk mengetahui variabel bebas yang mempunyai pengaruh dominan terhadap variabel terikat adalah dengan melihat koefisien regresi variabel bebas yang terbesar atau melihat dari nilai R Square secara parsial.

Koefisien determinasi $\left(\mathrm{R}^{2}\right)$ pada intinya mengukur seberapa jauh kemampuan model dalam menerangkan variasi variabel dependen. Nilai koefisien determinasi adalah nol dan satu. Nilai $\mathrm{R}^{2}$ yang kecil berarti kemampuan variabel-variabel independen dalam menjelaskan variasi variabel dependen amat terbatas.

Nilai yang mendekati satu berarti variabel-variabel independen memberikan hampir semua informasi yang dibutuhkan untuk memprediksi variasi variabel dependen. Secara umum koefisien determinasi untuk data silang (crossection) relative rendah karena ada variasi yang besar antara masing-masing pengamatan.

Guna keperluan pelaksanaan proses analisis data penelitian, digunakan alat bantu program komputer yaitu program SPSS versi 16.0

\section{HASIL DAN PEMBAHASAN}

\section{Hasil Penelitian}

\section{Uji Normalitas}

Uji normalitas bertujuan untuk menguji apakah dalam model regresi, variabel pengganggu atau residual telah terdistribusi normal atau tidak. Hal ini penting karena dalam uji regresi semua mengasumsikan nilai residual mengikuti distribusi normal. Jika 
asumsi normalitas tidak terpenuhi, maka akan terjadi hasil uji statistik tergradasi. Model regresi yang baik adalah memiliki distribusi data normal atau mendekati normal.

Tabel 1

Hasil Uji Normalitas dengan

One-Sample Kolmogorov-Smirnov Test

\begin{tabular}{|c|c|c|c|}
\hline $\begin{array}{c}\text { Nama } \\
\text { Variabel }\end{array}$ & $\begin{array}{c}\text { Nilai Asymp. Sig. (2- } \\
\text { tailed) }\end{array}$ & $\begin{array}{c}\text { Taraf } \\
\text { Signifikansi }\end{array}$ & Keputusan \\
\hline $\begin{array}{c}\text { Laba } \\
\text { Bank Syariah }\end{array}$ & 0,087 & 0,05 & Normal \\
\hline $\begin{array}{c}\text { CSR } \\
\text { Dana Qardh }\end{array}$ & 0,262 & 0,05 & Normal \\
\hline $\begin{array}{c}\text { CSR } \\
\text { Dana ZIS }\end{array}$ & 0,060 & 0,05 & Normal \\
\hline
\end{tabular}

Sumber: Data sekunder diolah, 2015

Dari tabel 4.3 diperoleh hasil :

Nilai Asymp. Sig. (2-tailed), variabel terikat laba Bank Syariah adalah 0,087 > 0,05. Dengan demikian H1 diterima, H0 ditolak. Hal ini berarti variabel laba Bank Syariah terdistribusi normal.

Nilai Asymp. Sig. (2-tailed), variabel Corporate Social Responsibility Dana Qardh adalah 0,262 > 0,05. Dengan demikian H1 diterima, H0 ditolak. Hal ini berarti variabel Corporate Social Responsibility Dana Qardh terdistribusi normal.

Nilai Asymp. Sig. (2-tailed), variabel Corporate Social Responsibility dana ZIS (zakat, infaq, shadaqah) adalah 0,060 > 0,05. Dengan demikian H1 diterima, Ho ditolak. Hal ini berarti variabel Corporate Social Responsibility Dana ZIS (Zakat, Infaq dan Shadaqah) terdistribusi normal.

\section{Uji Asumsi Klasik}

\section{a. Heteroskedasitas}

Pengujian gejala heteroskedastisitas menggunakan metode scatterplot dengan cara melihat pola gambar scatterplot model tersebut. Tidak terdapat heteroskedasitas apabila: 1) penyebaran titik-titik data sebaiknya tidak berpola; 2) titik-titik data menyebar di atas dan di bawah atau disekitar angka 0 dan 3) titik-titik data tidak mengumpul hanya di atas atau di bawah saja. 


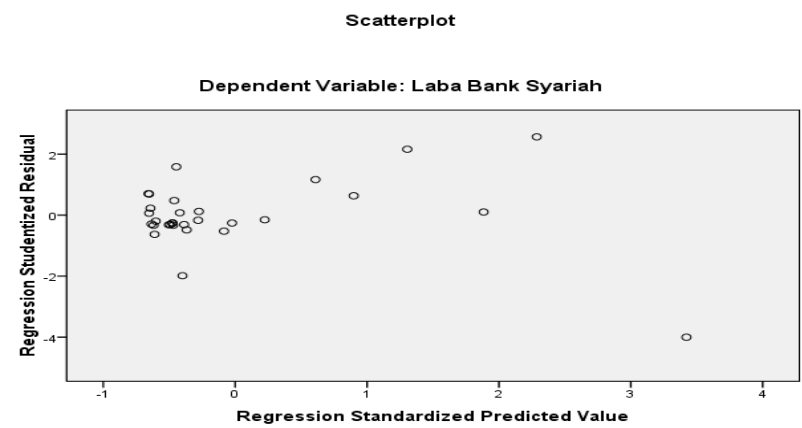

Grafik 2

Scatterplot Uji Heteroskedastisitas

Sumber: Data SPSS, 2015

Dari gambar diatas dapat dilihat bahwa titik-titik data mengumpul disekitar angka 0 sehingga dalam model regresi terjadi heteroskedastisitas. Hal ini dikarenakan desain penelitian menggunakan data cross sectional.

\section{Uji Multikoliniearitas}

Multikolinieritas berarti adanya hubungan linier yang kuat antara variabel bebas yang satu dengan variabel bebas yang lain dalam model regresi. Jika dalam model regresi terjadi hubungan yang kuat antar variabel bebas mengakibatkan sulit mengukur pengaruh masing-masing variabel bebas, karena pengaruh suatu variabel bebas tidak dapat dilepaskan dari pengaruh variabel bebas yang lain. Pengujian multikolinieritas dengan melihat nilai VIF (Variance Inflation Factor), multikolinieritas terjadi jika nilai VIF lebih besar dari 10.26

\section{Tabel 2}

Hasil Uji Multikolonieritas

\begin{tabular}{|c|c|c|c|}
\hline \multicolumn{4}{|c|}{ Coefficients $^{\mathrm{a}}$} \\
\hline & & \multicolumn{2}{|c|}{ Collinearity Statistics } \\
\hline \multicolumn{2}{|c|}{ Model } & Tolerance & VIF \\
\hline \multirow[t]{2}{*}{1} & CSR Dana Qardh & .861 & 1.161 \\
\hline & CSR Dana ZIS & .861 & 1.161 \\
\hline
\end{tabular}

a. Dependent Variable: Laba Bank Syariah

Sumber : data SPSS, 2015

\footnotetext{
${ }^{26}$ Agus Eko Sudjianto, Aplikasi Statistik dengan SPSS 16.0, (STAIN Tulungagung, 2009), hal. 79.
} 
Dari tabel 4.4 uji multikolinieritas dapat dilihat bahwa variabel-variabel independen tidak berkorelasi sempurna dengan variabel independen yang lain ditunjukkan nilai VIF masing-masing variabel Corporate Social Responsibility Dana Qardh dan Dana ZIS < $10(1,161<10)$ dengan demikian tidak terjadi multikolinieritas dalam model regresi yang dianalisis atau bisa dikatakan model terbebas dari multikolinieritas.

\section{Uji Autokorelasi}

Tabel 3

Hasil Uji Autokorelasi

\begin{tabular}{|c|c|c|c|}
\hline & \multicolumn{3}{|c|}{ Model Summary ${ }^{b}$} \\
\hline & Model & $\begin{array}{l}\text { Std. Error of } \\
\text { the Estimate }\end{array}$ & $\begin{array}{l}\text { Durbin- } \\
\text { Watson }\end{array}$ \\
\hline & 1 & $1.65907 \mathrm{E} 5$ & 2.081 \\
\hline Qardh & \multicolumn{3}{|c|}{ a. Predictors: (Constant), CSR Dana ZIS, CSR Dana } \\
\hline & \multicolumn{3}{|c|}{ b. Dependent Variable: Laba Bank Syariah } \\
\hline
\end{tabular}

Sumber: data SPSS, 2015

Dari gambar uji autokorelasi dikemukakan bahwa hasil $\mathrm{d}=2,081$. Berdasarkan kaidah keputusan Durbin Watson d test terletak pada range 1,65 < DW < 2,35 $(1,65<2,081$ $<2,35$ ) dengan keputusan menerima $\mathrm{H}_{0}$ menolak Ha (tidak ada korelasi positif atau negatif). Jadi dapat disimpulkan bahwa model regresi tidak ada masalah Autokorelasi.

5. Analisis Regresi Linier Berganda

Tabel 4

Hasil Uji Regresi Linier Berganda

\begin{tabular}{|l|l|l|}
\hline \multicolumn{3}{|c|}{ Coefficients $^{\mathbf{a}}$} \\
\hline \multirow{2}{*}{ Model } & \multicolumn{2}{|c|}{ Unstandardized Coefficients } \\
\cline { 2 - 3 } & B & Std. Error \\
\hline (Constant) & 87273.208 & 43002.635 \\
\hline CSR Dana Qardh & -1.288 & 42.967 \\
\hline CSR Dana ZIS & 9.374 & 2.664 \\
\hline a. Dependent Variable: Laba Bank Syariah \\
\hline
\end{tabular}

Sumber: data SPSS, 2015 
Tabel Coeffisients di atas untuk menggambarkan persamaan regresi sebagai berikut :

$Y=87.273,208-1,288 X_{1}+9,374 X_{2}$

Konstanta sebesar 87.273,208 menyatakan bahwa jika tidak ada Corporate Social Responsibility Dana Qardh dan Dana Zakat, Infaq, dan Shadaqah, maka Laba Bank Syariah sebesar $87.273,208$ satuan.

Koefisien regresi $X_{1}$ sebesar -1,288 menyatakan bahwa setiap pengurangan (karena tanda negatif) 1 satuan, Corporate Social Responsibility Dana Qardh akan meningkatkan Laba Bank Syariah sebesar 1,288 satuan dan sebaliknya jika Corporate Social Responsibility Dana Qardh naik sebesar 1 satuan, maka Laba Bank Syariah juga diprediksi mengalami penurunan sebesar 1,288 satuan dengan anggapan X2 tetap.

Koefisien regresi X2 sebesar 9,374 menyatakan bahwa setiap penambahan (karena tanda positif) 1 satuan, Corporate Social Responsibility Dana Zakat, Infaq, dan Shadaqah akan meningkatkan Laba Bank Syariah sebesar 9,374 satuan. Dan sebaliknya jika Corporate Social Responsibility Dana Zakat, Infaq, dan Shadaqah turun sebesar 1 satuan, maka Laba Bank Syariah juga diprediksi mengalami penurunan sebesar 9,374 satuan dengan anggapan $\mathrm{X}_{1}$ tetap.

\section{Uji Statistik F}

Tabel 5

Hasil Uji F

\begin{tabular}{|c|c|c|}
\hline & & ANOVA $^{\mathbf{b}}$ \\
\hline Model & $\mathrm{F}$ & Sig. \\
\hline Regression & 7.142 & $.003^{\mathrm{a}}$ \\
\hline Residual & & \\
\hline Total & & \\
\hline a. Predictors: (Constant), CS & ZIS, CSF & rdh \\
\hline b. Dependent Variable: Laba & yariah & \\
\hline
\end{tabular}
Sumber: data SPSS, 2015

Dari tabel ANOVA di atas, terbaca $F$ hitung sebesar 7,142 dengan tingkat signifikansi 0,003. Oleh karena probabilitas 0,003 jauh lebih kecil dari 0,05 (dalam kasus ini menggunakan taraf signifikansi atau $\alpha=5 \%$ ), maka model regresi bisa dipakai untuk memprediksi Laba Bank Syariah. 
Pada tingkat kepercayaan 95\% $(\alpha=5 \%)$ dan $\mathrm{k}=2, \mathrm{n}=30$ maka diperoleh nilai $\mathrm{F}_{\text {tabel }}$ = 3,35 sedangkan nilai Fhitung $=7,142$ sehingga $F_{\text {hitung }}>F_{\text {tabel }}$ dan nilai probabilitas 0,003 lebih kecil dari 0,05 teruji bahwa kedua variabel bebas berpengaruh signifikan terhadap laba Bank Syariah \{PT. Bank Negara Indonesia (BNI) Syariah, PT. Bank Syariah Mandiri (BSM) dan PT. Bank Mega Syariah\}. Hasil Uji F tersebut menunjukkan bahwa hipotesis yang diajukan teruji.

\section{Uji Statistik T}

Tabel 6

Hasil Uji T

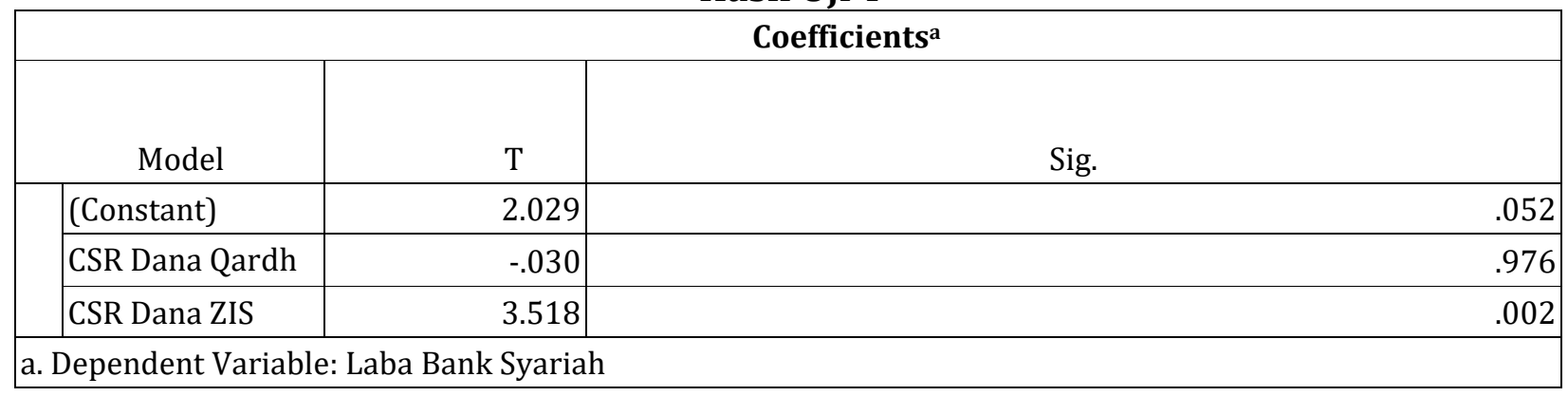
Sumber: data SPSS, 2015

a) Menguji signifikansi konstanta pada model linier $(\alpha)$

Ho $=$ Koefisien regresi $\alpha$ tidak signifikan

$\mathrm{H}=$ Koefisien regresi $\alpha$ signifikan

Dalam tabel coefficients diperoleh nilai Sig. sebesar 0,052 dibandingkan dengan taraf signifikansi $(\alpha=5 \%)$ 0,05 maka:

Sig. $\alpha$

$0,052>0,05$

cara lainnya adalah dengan membandingkan antara t-hitung dengan t-tabel $[2,029$ $>1$,703). Karena t-hitung $>$ t-tabel maka dapat disimpulkan bahwa konstanta pada model ini menerima Ho, yang berarti koefisien regresi $\alpha$ signifikan.

b) Menguji signifikansi koefisien regresi variabel Corporate Social Responsibility Dana Qardh $\left(\mathrm{X}_{1}\right)$

Ho = Koefisien regresi Corporate Social Responsibility Dana Qardh tidak signifikan

$\mathrm{H}=$ Koefisien regresi Corporate Social Responsibility Dana Qardh signifikan

Sig. $\alpha$ 
$0,976>0,05$

cara lainnya adalah dengan membandingkan antara t-hitung dengan t-tabel ($0,030<1,703)$. Karena nilai Sig. $>\alpha$ dan t-hitung $<\mathrm{t}$-tabel maka dapat disimpulkan bahwa Corporate Social Responsibility Dana Qardh pada model ini menerima Ho, yang berarti koefisien regresi Corporate Social Responsibility Dana Qardh tidak signifikan.

c) Menguji signifikansi koefisien regresi variabel Corporate Social Responsibility Dana Zakat, Infaq, dan Shadaqah $\left(\mathrm{X}_{2}\right)$

Ho = Koefisien regresi Corporate Social Responsibility Dana Zakat, Infaq dan Shadaqah tidak signifikan

H1 = Koefisien regresi Corporate Social Responsibility Dana Zakat, Infaq dan Shadaqah signifikan

Sig. $\alpha$

$0,002<0,05$

cara lainnya adalah dengan membandingkan antara t hitung dengan $t$ tabel $(3,518$ $>$ 1,703). Karena nilai Sig. $<\alpha$ dan t-hitung $>$ t-tabel maka dapat disimpulkan bahwa Corporate Social Responsibility Dana Zakat, Infaq dan Shadaqah pada model ini menolak Ho, yang berarti koefisien regresi Corporate Social Responsibility Dana Zakat, Infaq dan Shadaqah adalah signifikan.

\section{Koefisien Determinasi}

Tabel 7

Hasil Uji $\mathbf{R}^{2}$

\begin{tabular}{|l|c|}
\hline \multicolumn{2}{|c|}{ Model Summary } \\
\hline Model & Adjusted R Square \\
\hline 1 & \\
\hline a. Predictors: (Constant), CSR Dana ZIS, CSR Dana Qardh \\
\hline
\end{tabular}

Sumber: data SPSS, 2015

Angka Adjusted R Square adalah 0,298, artinya 29,8\% variabel terikat kuantitas produk yang terjual dijelaskan oleh variabel bebas yang terdiri dari Corporate Social Responsibility Dana Qardh dan Corporate Social Responsibility Dana Zakat, Infaq, dan Shadaqah dan sisanya 70,2\% dijelaskan oleh variabel lain diluar variabel yang digunakan. 
Jadi sebagian besar variabel terikat dijelaskan oleh variabel-variabel bebas yang digunakan dalam model. Dengan demikian pengaruh Corporate Social Responsibility Dana Qardh dan Dana Zakat, Infaq dan Shadaqah terhadap Laba Bank Syariah termasuk dalam kategori rendah atau lemah.

\section{Pembahasan}

Hipotesis pertama menyatakan bahwa Corporate Social Responsibility Dana Qardh tidak memiliki pengaruh yang signifikan terhadap Laba Bank Syariah, hal ini dapat diketahui dari nilai Sig. $>\alpha$ dan t-hitung < t-tabel $(0,976>0,05$ dan $-0,030<1,703)$, maka dapat disimpulkan bahwa Corporate Social Responsibility Dana Qardh pada model ini menerima Ho, menolak Ha yang berarti koefisien regresi Corporate Social Responsibility Dana Qardh tidak berpengaruh signifikan terhadap Laba Bank Syariah.

Tidak terbuktinya hipotesis yang mengatakan bahwa Corporate Social Responsibility Dana Qardh tidak berpengaruh signifikan terhadap Laba Bank Syariah pada penelitian ini karena disebabkan beberapa hal, salah satunya adalah Dana Qardh yang dikeluarkan oleh Bank Syariah berupa produk untuk menyumbang usaha yang sangat kecil atau membantu sektor sosial. Disisi lain, pengertian Qardh sendiri adalah pinjaman tanpa imbalan yang memungkinkan peminjam untuk menggunakan dana tersebut selama jangka waktu tertentu dan wajib mengembalikan dalam jumlah yang sama pada akhir periode yang telah disepakati. Disini pihak Bank tidak boleh meminta imbalan kepada peminjam dalam bentuk apapun, karena Dana Qardh berprinsip ta'awwun atau tolong menolong. Namun apabila si peminjam dengan sukarela memberi imbalan kepada Bank tidak dipermasalahkan dan diperbolehkan. Sehingga dalam hal ini pihak Bank Syariah tidak bisa mengambil untung atau laba besar dari produk tersebut.

Pengaruh Corporate Social Responsibility dana ZIS (Zakat, Infaq dan Shadaqah) terhadap Laba Bank Syariah. Dilihat dari hasil uji parsialnya (uji t) menunjukkan bahwa variabel yakni Corporate Social Responsibility Dana Zakat, Infaq dan Shadaqah memiliki pengaruh yang signifikan terhadap Laba Bank Syariah, hal ini dapat diketahui dari nilai Sig. $<\alpha$ dan t-hitung $>$ t-tabel $(0,002<0,05$ dan 3,518 > 2,048) maka dapat disimpulkan 
bahwa Corporate Social Responsibility Dana Zakat, Infaq dan Shadaqah pada model ini menolak Ho, yang berarti koefisien regresi Corporate Social Responsibility Dana Zakat, Infaq dan Shadaqah adalah signifikan.

Hal ini sesuai dengan penelitian sebelumnya bahwa nilai kesehatan kinerja keuangan, modal dan laba mempunyai pengaruh positif terhadap kemampuan zakat perusahaan. Hasil ini menunjukkan bahwa kinerja keuangan yang membaik akan meningkatkan kemampuan zakat perusahaan. Jika kinerja keuangan perusahaan dalam mengalami peningkatan akan berdampak pada peningkatan alokasi dana zakat yang disalurkan, begitu juga sebaliknya peningkatan alokasi dana zakat yang disalurkan akan berdampak pada kinerja keuangan berupa Laba Bank Syariah.

Pengaruh Corporate Social Responsibility Dana Qardh dan dana ZIS (Zakat, Infaq dan Shadaqah) terhadap Laba Bank Syariah. Hasil analisis regresi linier berganda menunjukkan bahwa kedua variabel secara bersama-sama memiliki pengaruh signifikan terhadap Laba Bank Syariah. Bank Syariah yang dimaksud dalam penelitian ini diantaranya: PT. Bank Negara Indonesia (BNI) Syariah, PT. Bank Syariah Mandiri (BSM) dan PT. Bank Mega Syariah, hal ini dapat diketahui dari hasil uji F yang memiliki nilai probabilitas sebesar 0,003 yang berarti signifikan di atas $99 \%$.

Kenyataan tersebut menunjukkan bahwa hipotesis yang mengemukakan bahwa variabel yang mempengaruhi Laba Bnak Syariah yang meliputi Corporate Sosial Responsibility Dana Qardh dan Dana Zakat, Infaq, dan Shadaqah mempunyai pengaruh secara signifikan baik secara simultan terhadap jumlah Laba pada Bank Syariah adalah terbukti benar, karena terbukti bahwa kedua variabel secara bersama-sama memiliki pengaruh signifikan terhadap Laba Bank Syariah.

Sedangkan hipotesis selanjutnya yang mengemukakan bahwa variabel Corporate Social Responsibility Dana Zakat, Infaq, dan Shadaqah merupakan variabel yang paling dominan pengaruhnya terhadap Laba Bank Syariah terbukti kebenarannya, karena hasil analisis menunjukkan bahwa variabel Corporate Social Responsibility Dana Zakat, Infaq, dan Shadaqah yang bernilai koefisien regresi 9,374 memiliki pengaruh dominan terhadap 
Laba Bank Syariah \{PT. Bank Negara Indonesia (BNI) Syariah, PT. Bank Syariah Mandiri (BSM) dan PT. Bank Mega Syariah\}.

Hasil uji $\mathrm{R}^{2}$ menunjukkan bahwa nilai Adjusted $R$ Square adalah 0,298, artinya 29,8\% variabel terikat kuantitas produk yang terjual dijelaskan oleh Corporate Social Responsibility Dana Qardh dan Dana Zakat, Infaq, dan Shadaqah dan sisanya 70,2\% adalah variabel lain. Dimana nilai tersebut cukup jauh dari 100\% sehingga tingkat pengaruh Corporate Social Responsibility Dana Qardh dan Dana Zakat, Infaq dan Shadaqah terhadap Laba Bank Syariah termasuk dalam kategori rendah atau lemah.

Dari keseluruhan hasil uji di atas menunjukkan bahwa Corporate Social Responsibility Dana Qardh dan Dana Zakat, Infaq dan Shadaqah memiliki pengaruh yang signifikan terhadap Laba Bank Syariah. Jadi dalam hal ini semakin tinggi dana Corporate Social Responsibility yang dikeluarkan maka semakin baik citra Bank Syariah dan semakin meningkat juga kepercayaan masyarakat untuk mempercayakan sebagian dananya diamanahkan kepada Bank Syariah. Selanjutnya, dengan semakin meningkatnya perolehan jumlah dana pihak ketiga maka secara langsung juga berpengaruh terhadap Laba Bank Syariah.

\section{KESIMPULAN}

Berdasarkan hasil analisis data dan pembahasan hasil penelitian, maka dapat diperoleh beberapa kesimpulan sebagai berikut:

1. Corporate Social Responsibility Dana Qardh tidak memiliki pengaruh terhadap Laba Bank Syariah. Dari hasil analisis data dapat diketahui bahwa nilai signifikansi lebih besar daripada $\alpha$ dan t-hitung lebih kecil daripada t-tabel sehingga koefisien regresi Corporate Social Responsibility Dana Qardh tidak berpengaruh signifikan terhadap Laba Bank Syariah secara parsial.

2. Corporate Social Responsibility Dana Zakat, Infaq, dan Shadaqah memiliki pengaruh yang signifikan terhadap Laba Bank Syariah, hal ini dapat diketahui dari nilai signifikansi lebih kecil daripada $\alpha$ dan t-hitung lebih besar daripada t-tabel sehingga 
koefisien regresi Corporate Social Responsibility Dana Zakat, Infaq, dan Shadaqah berpengaruh signifikan terhadap Laba Bank Syariah secara parsial.

3. Secara simultan Corporate Social Responsibility Dana Qardh dan Dana Zakat, Infaq dan Shadaqah memiliki pengaruh yang signifikan terhadap Laba Bank Syariah, hal ini dapat diketahui dari nilai f-hitung lebih besar daripada f-tabel sehingga koefisien regresi Corporate Social Responsibility Dana Zakat, Infaq, dan Shadaqah berpengaruh signifikan terhadap Laba Bank Syariah. Bukti empiris penelitian ini mendukung hipotesa yang menyatakan bahwa tingkat pengungkapan informasi Corporate Social Responsibility dalam laporan keuangan semester Bank Syariah berpengaruh positif terhadap Laba Bank Syariah. Hasil uji $\mathrm{R}^{2}$ menunjukkan nilai Adjusted R Square jauh dari 100\%. Dengan demikian, tingkat pengaruh Corporate Social Responsibility Dana Qardh dan Dana Zakat, Infaq dan Shadaqah terhadap Laba Bank Syariah termasuk dalam kategori rendah atau lemah. 


\section{DAFTAR RUJUKAN}

Ahmad asy-Syarbasyi. 1987. al Mu'jam al Iqtisad al-Islami. Beirut: Dar Alamil Kutub, 1987); Sayyid Sabiq, Fiqhus Sunnah (Beirut: Darul-Kitab al-Arabi, 1987), cetakan ke-8, vol.III.

Ambadar, Jackie. 2008. CSR dalam praktik di Indonesia. Jakarta: PT Elex Media Komputindo.

Antonio, Muhammad Syafi'i. 2001. Bank Syariah: dari Teori ke Praktik. Jakarta: Gema Insani Press.

Arikunto, Suharsimi. 1998. Prosedur Penelitian Suatu Pendekatan Praktek. Jakarta: Rineka Cipta.

Beekum, Rafik Issa. 1996. Etika Bisnis Islam. t.t.p.: university of Nevada November I.

Bungin, Burhan. 2008. Metode Penelitian Kuantitatif. Jakarta: Kencana. Cendekia.

Capra, M. Umer. 2000. Sistem Moneter Islam. Jakarta: Gema Insani Press \& Tazkia

Elvinaro, Ardianto. 2011. Metodologi Penelitian untuk Public Relations-Kuantitatif dan Kualitatif. Bandung: Simbiosa Rekatama Media.

Ghozali, Imam. 2009. Aplikasi Analisis Multivariate Dengan Program SPSS. Semarang: UNDIP.

2011. Aplikasi Analisis Multivariate Dengan Program SPSS. Semarang: BP Universitas Diponegoro.

Hardiansyah. "Lingkungan, Masyarakat dan Tanggung Jawab Sosial Perusahaan CSR", dalam http://fema.ipb.ac.id, diakses tanggal 08 Agustus 2014.

Hariwijaya, M. 2007. Metodologi Dan Teknik Penulisan Skripsi, Tesis, Dan Disertasi. Yogyakarta: elMatera Publishing.

Ikhwan, A, Pengaruh Nilai Kesehatan Kinerja Keuangan, Modal Dan Laba Terhadap Kemampuan Zakat Perusahaan dalam https://publikasiilmiah.ums.ac.id. Diakses tanggal 15 Maret 2015.

Ikhwanudin. t.h."Tinjauan Hukum Islam terhadap Pendistribusian Zakat, Infaq dan Shadaqah (ZIS) di BAZIZ Kab. Gunung Kidul Prop.DIY. t.tp.: t.p.

Irianto, Agus. 2007. Statistik: Konsep Dasar \& Aplikasinya. Jakarta: Kencana.

James, Stice, dll. 2009. Akuntansi Keuangan. Jakarta: Salemba Empat.

Januarti, Indira dan Apriyanti, Dini, 2005. "Pengaruh Tanggung Jawab Sosial Perusahaan Terhadap Kinerja Keuangan,” Jurnal MAKSI. Vol 5 No.2 Agustus: 227-243. 
Karim, Adiwarman. 2006. Bank Islam: Analisis Fikih dan Keuangan. Jakarta: PT. Raja Grafindo Persada.

Lindrawati, Felicia dan Budianto, 2008. "Pengaruh Corporate Social Responsibility Terhadap Kinerja Keuangan Perusahaan yang Terdaftar sebagai 100 Best Corporate Citizens oleh KLD Research and Analytics," Majalah Ekonomi. Tahun XVIII, No. 1 April : 6683

Masyhuri. Teori Ekonomi dalam Islam. Yogyakarta: Kreasi Wacana.

Mauludi, Ali. 2012. Teknik Memahami Statistika 2. Jakarta Timur: Alim’s Publishing.

Muhammad. 2002. Etika Bisnis Islam. Yogyakarta: Akademi Manajemen Perusahaan YKPN. 2002. Manajemen Bank Syariah. Yogyakarta: AMP YKPN.

Saeed, Abdullah. 2008. Bank Islam dan Bunga: Studi Kritis Larangan Riba dan Interpretasi Kontemporer. Yogyakarta: Pustaka Pelajar. Graha Ilmu.

Sarwono, Jonathan. 2006. Metode Penelitian Kuantitatif \& Kualitatif. Yogyakarta:

Soemarso SR. 2004. Akuntansi Suatu Pengantar. Jakarta: Salemba Empat.

Sudarmanto, Gunawan. 2005. Analisis Regresi Linier Ganda dengan SPSS, Yogyakarta: Graha Ilmu.

Sudjianto, Agus Eko. 2009. Aplikasi Statistik dengan SPSS 16.0. STAIN Tulungagung.

Sugiyono. 1999. Metode Penelitian Bisnis. Bandung: Alfabeta. 2011. Statistik Untuk Penelitian. Bandung: Alfabeta.

Suhandari, M. Putri. Schema CSR. Kompas edisi 4 Agustus 2007.

Sulhan, M \& Ely Siswanto. 2008. Manajemen Bank: Konvensional \& Syariah. Malang: UIN_Malang Press.

Suwardjono.2008. Teori Akuntansi: Perekayasaan Pelaporan Keuangan. Yogyakarta: BPFE.

Triton, PB. 2006. Riset Statistik Parametrik. Yogyakarta: ANDI.

Usman, Husaini \& Purnomo Setyadi Akbar. 2006. Pengantar Statistik. Jakarta: PT. Bumi Aksara.

Wibisono, Yusuf. 2007. Membedah Konsep \& Aplikasi CSR. Gresik: Fascho Publishing. 